MaPan : Jurnal Matematika dan Pembelajaran

p-ISSN: 2354-6883 ; e-ISSN: 2581-172X

Volume 5, No 2, December 2017 (201-215)

DOI: https://doi.org/10.24252/mapan.v5n2a4

\title{
PERBANDINGAN METODE DEDUKTIF DENGAN INDUKTIF TERHADAP HASIL BELAJAR MATEMATIKA DITINJAU DARI MOTIVASI BELAJAR SISWA
}

\author{
Samsul Bahri'), Andi Ika Prasasti Abrar'), Andi Dian Angriani3) \\ 1,2,3 Jurusan Pend. Matematika Fakultas Tarbiyah dan Keguruan UIN Alauddin Makassar \\ 1,2,3Kampus II: Jalan HM. Yasin Limpo Nomor 36 Samata-Gowa \\ E-mail: ancyubahri@gmail.com ${ }^{1}$, , asty_math03@yahoo.co.id ${ }^{2}$, \\ dian.angriani@uin-alauddin.ac.id ${ }^{3}$ )
}

Submitted: 29-09-2017, Revised: 18-10-2017, Accepted: 18-10-2017

\begin{abstract}
Abstrak:
Penelitian ini bertujuan untuk mengetahui gambaran hasil belajar matematika yang menggunakan metode deduktif dan induktif serta perbedaan yang signifikan antara metode deduktif dengan induktif terhadap hasil belajar matematika ditinjau dari motivasi belajar siswa. Jenis penelitian ini adalah penelitian quasi eksperiment. Populasi dalam penelitian ini ialah seluruh siswa kelas XII IPS MAN Wajo terdiri dari 4 kelas, yang berjumlah 86 siswa. Penentuan sampel dengan cara random. Instrumen yang digunakan pada penelitian ini adalah tes hasil belajar dan angket motivasi belajar matematika. Teknik analisis yang digunakan adalah statistik deskriptif dan analisis statistik inferensial dengan uji F ANAVA dengan interaksi. Berdasarkan hasil analisis statistika deskriptif, diperoleh nilai rata-rata hasil belajar siswa menggunakan metode deduktif adalah 74,91 dan metode induktif adalah 88,95, nilai rata-rata motivasi belajar matematika siswa menggunakan metode deduktif adalah 65,73 dan metode induktif adalah 68,23 . Berdasarkan analisis inferensial, diperoleh $\mathrm{F}_{0}>\mathrm{F}$ tabel $(3,911>3,24)$ dan nilai Sig. $<\alpha=0,021<0,05$, maka $H_{\mathrm{o}}$ ditolak, artinya terdapat perbedaan yang signifikan antara metode deduktif dengan metode induktif terhadap hasil belajar matematika ditinjau dari motivasi belajar siswa kelas XII IPS MAN Wajo.
\end{abstract}

Kata Kunci: Metode Deduktif, Metode Induktif, Hasil Belajar, Motivasi Belajar

\section{THE COMPARISON OF INDUCTIVE METHOD AND DEDUCTIVE METHOD TOWARDS THE LEARNING OUTCOME IN MATHEMATICS BASED ON THE LEARNING MOTIVATION OF STUDENTS}

\begin{abstract}
:
This study aims to find out the learning outcome in mathematics using inductive method and deductive method, and also the description of students' learning motivation using Inductive Method, the students' learning motivation using Deductive Method, to know the significant difference between Inductive Method and Deductive Method on the learning outcome in mathematics based on the learning motivation of students in social sciences major of grade 12 of Islamic Senior High School Wajo, Wajo regency. This research is a quasi-experimental design. The population was all the students of social sciences in grade 12 of Islamic Senior High school Wajo which consisted of 86 students. The sampling technique was simple random sampling. Instruments used were the learning outcomes test, questionnaire on learning
\end{abstract}


motivation of mathematics and observation sheet. The techniques of analysis used were descriptive statistics and inferential statistical analysis with $F$ test of ANAVA with interaction. Based on the results of data analysis using descriptive statistics for student's learning outcome using Deductive Method, the average score of this group was 74.91. On the other hand, the students' learning outcome using Inductive Method reached the average score of 88.95. Theaverage score of students' learning motivation in mathematics using deductive method was 65.73. As for students' learning motivation using Deductive Method, the average score was 68.23. The result of ANAVA for hypothesis I is that $F_{0}>F$ table, thus Ho is rejected. Therefore, it is concluded that there is a significant difference between Inductive Method and Deductive Method on Mathematics Learning outcome. As for the hypothesis II, the result obtained shows that $F_{0}>F$ table, thus Ho rejected, then it is concluded that there are differences between students who have high motivation, moderate motivation and low motivation in their learning outcomes in mathematics. For the hypothesis III, it is revealed that $F_{0}>F$ table (3.911> 3.24) and the Sig value. $<\alpha=0.021<0.05$, hence Ho is rejected, where it indicates that there is a significant difference between Inductive Method and Deductive Method towards the learning outcome in mathematics based on the learning motivation of students in social sciences major of grade 12 of Islamic Senior High School Wajo, Wajo regency.

Keywords: Deductive Method, Inductive Method, Learning Outcome, Learning Motivation

How to Cite: Bahri, S., Abrar, A. I. P., \& Angriani, A. D. (2017). Perbandingan Metode Deduktif dengan Induktif terhadap Hasil Belajar Matematika Ditinjau dari Motivasi Belajar Siswa. MaPan : Jurnal Matematika dan Pembelajaran, 5(2), 201-215.

$\mathrm{P}$ endidikan memiliki peranan penting dalam meningkatkan kualitas sumber daya manusia. Pendidikan merupakan sebuah proses dengan metode-metode tertentu sehingga seseorang memperoleh pengetahuan, pemahaman, dan cara bertingkah laku sesuai dengan kebutuhan. Menurut UU No. 20 Tahun 2003 tentang Sistem Pendidikan Nasional menyatakan bahwa Pendidikan adalah usaha sadar dan terencana untuk mewujudkan suasana belajar dan proses pembelajaran agar peserta didik secara aktif mengembangkan potensi dirinya untuk memiliki kekuatan spiritual keagamaan, pengendalian diri, kepribadian, kecerdasan, akhlak mulia, serta keterampilan yang diperlukan oleh dirinya, masyarakat, bangsa, dan negara. Berdasarkan pengertian tersebut, pendidikan pada hakekatnya suatu kegiatan secara sadar dan disengaja, serta penuh tanggung jawab yang dilakukan oleh guru kepada peserta didik sehingga timbul interaksi dari keduanya agar peserta didik mencapai tujuan yang dicita-citakan dan berlangsung terus menerus. Bangsa Indonesia menaruh harapan besar kepada pendidik dalam perkembangan masa depan bangsa, karena dari sanalah generasi penerus dibentuk (Angriani, 2014). 
Menurut Abdurrahman dalam Jihad dan Haris (2012: 14), hasil belajar adalah kemampuan yang diperoleh anak setelah melalui kegiatan belajar. Belajar itu sendiri merupakan suatu proses dari seseorang yang berusaha untuk memperoleh suatu bentuk perubahan perilaku yang relatif menetap. Berdasarkan pengamatan yang dilakukan di MAN Wajo khususnya kelas XII IPS bahwa hasil belajar matematika kurang memuaskan. Hal ini dapat dilihat pada saat ulangan harian, sebagian besar siswanya masih banyak yang mengulang/remedial. Misalnya saja, salah seorang siswa mempeoleh nilai dibawah KKM pada saat ulangan harian dengan materi Integral, sedangkan KKM mata pelajaran matematika adalah 70 . Namun dengan berbagai metode pembelajaran yang ada, di sekolah ini belum dimaksimalkan sepenuhnya oleh guru. Ini didasarkan pada hasil observasi peneliti bahwa dalam melaksanakan kegiatan belajar mengajar, kebanyakan guru masih menggunakan model pembelajaran langsung yang berpusat pada guru sehingga proses belajar mengajar belum efektif, namun sudah ada sebagian guru yang menggunakan model pembelajaran yang sudah efektif seperti, pembelajaran kooperatif dengan pendekatan scientific.

Metode pembelajaran yang dianggap tepat oleh peneliti untuk mengatasi masalah tersebut adalah metode deduktif dan metode induktif. Menurut Djumingin (2011: 7), metode pembelajaran deduktif pesan mulai dari hal umum menuju yang khusus, dari hal yang abstrak kepada hal-hal yang nyata, dari konsep-konsep yang abstrak kepada contoh-contoh yang konkrit, dari sebuah premis menuju ke kesimpulan yang logis. Menurut Aqib (2014: 117), metode induktif dimulai dengan pemberian berbagai kasus, contoh atau sebab yang mencerminkan suatu konsep atau prinsip. Kemudian siswa dibimbing untuk berusaha keras untuk mensintesiskan, merumuskan, atau menyimpulkan prinsip dasar dari pelajaran tersebut (Maryanto dan Mundilarto, 2013). Metode ini disebut metode discovery atau socratic.

Menurut Aunurrahman (2011: 177), faktor-faktor internal yang mempengaruhi proses belajar peserta didik antara lain: ciri khas/karakteristik peserta didik, sikap terhadap belajar, motivasi belajar, Sementara itu, Sanjaya (2012: 28) mengungkapkan bahwa dalam proses pembelajaran, motivasi merupakan salah satu aspek dinamis yang sangat penting. Siswa yang kurang berprestasi bukan disebabkan oleh kemampan yang kurang, tetapi dikarenakan tidak adanya motivasi untuk belajar sehingga siswa tidak berusaha untuk mengerahkan segala kemampuannya. Dengan demikian, bisa dikatakan siswa yang berprestasi rendah belum tentu disebabkan oleh 
kemampuan yang rendah pula, tetapi mungkin disebabkan oleh tidak adanya dorongan atau motivasi.

Oleh karena itu, dalam penelitian ini peneliti ingin membandingkan metode deduktif dengan metode induktif terhadap hasil belajar matematika ditinjau dari motivasi belajar siswa, dengan tujuan mengetahui gambaran metode deduktif dan induktif serta menegtahui ada tidaknya perbedaan dari kedua metode tersebut, yakni metode deduktif dan metode induktif terhadap hasil belajar ditinjau dari motivasi belajar siswa.

\section{METODE PENELITIAN}

Pendekatan yang digunakan peneliti adalah pendekatan kuantitatif dengan jenis penelitian yang digunakan adalah eksperimen semu (quasi experimental). Desain penelitian yang digunakan oleh peneliti adalah rancangan design factorial $3 \times 2$, dimana variabel dalam penelitian ini yaitu hasil belajar dari metode pembelajaran sebagai variabel $\mathrm{Y}$ dan motivasi belajar sebagai variabel $X$.

Tabel 1. Design Factorial $3 \times 2$

\begin{tabular}{ccc}
\hline \multirow{2}{*}{ Motivasi Belajar $(\mathbf{X})$} & \multicolumn{2}{c}{ Hasil Belajar $(\mathbf{Y})$} \\
\cline { 2 - 3 } & Deduktif $\left(\mathbf{Y}_{\mathbf{1}}\right)$ & Induktif $\left(\mathrm{Y}_{\mathbf{2}}\right)$ \\
\hline Tinggi $\left(\mathrm{X}_{1}\right)$ & $\mathrm{Y}_{1} \mathrm{X}_{1}$ & $\mathrm{Y}_{2} \mathrm{X}_{1}$ \\
Sedang $\left(\mathrm{X}_{2}\right)$ & $\mathrm{Y}_{1} \mathrm{X}_{2}$ & $\mathrm{Y}_{2} \mathrm{X}_{2}$ \\
Rendah $\left(\mathrm{X}_{3}\right)$ & $\mathrm{Y}_{1} \mathrm{X}_{3}$ & $\mathrm{Y}_{2} \mathrm{X}_{3}$ \\
\hline
\end{tabular}

Keterangan:

$\mathrm{Y}_{1} \mathrm{X}_{1}$ : Hasil belajar menggunakan metode deduktif ditinjau dari motivasi tinggi.

$\mathrm{Y}_{1} \mathrm{X}_{2}$ : Hasil belajar menggunakan metode deduktif ditinjau dari motivasi sedang.

$\mathrm{Y}_{1} \mathrm{X}_{3}$ : Hasil belajar menggunakan metode deduktif ditinjau dari motivasi rendah.

$\mathrm{Y}_{2} \mathrm{X}_{1}$ : Hasil belajar menggunakan metode induktif ditinjau dari motivasi tinggi.

$\mathrm{Y}_{2} \mathrm{X}_{2}$ : Hasil belajar menggunakan metode induktif ditinjau dari motivasi sedang.

$\mathrm{Y}_{2} \mathrm{X}_{3}$ : Hasil belajar menggunakan metode induktif ditinjau dari motivasi rendah. 
Instrumen dalam penelitian ini adalah tes dan angket. Untuk menentukan validitas item digunakan rumus korelasi product moment. Berdasarkan SPSS.20 diperoleh hasil validitas sebagai berikut:

Tabel 2. Hasil Uji Validitas

\begin{tabular}{ccc}
\hline Variabel & Nilai Terendah & Nilai Tertinggi \\
\hline Hasil Belajar & $-0,017$ & 0,823 \\
Motivasi Belajar & $-0,111$ & 0,772 \\
\hline
\end{tabular}

Pada variabel hasil belajar dengan jumlah item 8 yaitu 5 item yang valid dan 3 item yang tidak valid. Sedangkan untuk motivasi belajar dengan jumlah item 25 yaitu 20 item yang valid dan 5 item tidak valid.

Reliabilitas adalah sejumlah hasil suatu pengukuran dapat dipercaya. Uji reliabilitas menggunakan rumus alpha. Berdasarkan SPSS.20 diperoleh hasil sebagai berikut:

Tabel 3. Hasil Uji Reliabilitas

\begin{tabular}{ccc}
\hline Variabel & Cronbach's Alpha & N of Items \\
\hline Hasil Belajar & 0,494 & 24 \\
Motivasi Belajar & 0,902 & 21 \\
\hline
\end{tabular}

Teknik analisis data dibagi menjadi dua yaitu teknik analisis deskriptif dan teknik analisis inferensial. Teknik analisis deskriptif meliputi tabel distribusi frekuensi, minimum, maksimum, rata-rata (mean), standar deviasi, dan variansi. Sedangkan analisis inferensial menggunakan uji $F$ dengan ANAVA dua jalur, tetapi terlebih dahulu dilakukan uji normalitas data dan uji homogenitas varian semua menggunakan bantuan program SPSS 20. Selanjutkan dengan uji hipotesis dua pihak untuk mengetahui dugaan sementara yang dirumuskan oleh peneliti.

\section{HASIL PENELITIAN DAN PEMBAHASAN}

Deskripsi Hasil Belajar Matematika yang Menggunakan Metode Deduktif pada Siswa Kelas XII IPS MAN Wajo Kabupaten Wajo

Berikut ini adalah tabel hasil analisis deskriptif data hasil belajar matematika yang menggunakan metode deduktif pada siswa kelas XII IPS MAN Wajo Kabupaten Wajo. 
Tabel 4. Deskripsi Hasil Belajar Kelas Eksperimen 1

\begin{tabular}{lccccccc}
\hline \multicolumn{7}{c}{ Descriptive Statistics } \\
\hline & N & $\begin{array}{c}\text { Rang } \\
\text { e }\end{array}$ & Min & Max & Mean & $\begin{array}{c}\text { Std. } \\
\text { Deviatio } \\
\text { n }\end{array}$ & $\begin{array}{c}\text { Varianc } \\
\text { e }\end{array}$ \\
\hline $\begin{array}{l}\text { Posttest Kelas } \\
\text { Eksperimen 1 }\end{array}$ & 22 & 34,00 & 56,00 & 90,00 & 74,9091 & 9,46628 & 89,610 \\
$\begin{array}{l}\text { Valid N } \\
\text { (listwise) }\end{array}$ & 22 & & & & & & \\
\hline
\end{tabular}

Berdasarkan tabel 4, maka diperoleh skor maksimum pada post-test kelas eksperimen 1 adalah 90, sedangkan skor minimum pada post-test adalah 56, dan rata-rata yang diperoleh adalah 74,91.

\section{Deskripsi Motivasi Belajar yang Menggunakan Metode Deduktif pada Siswa Kelas XII IPS MAN Wajo Kabupaten Wajo}

Berikut ini adalah tabel hasil analisis deskriptif data motivasi belajar yang menggunakan metode deduktif pada siswa kelas XII IPS MAN Wajo Kabupaten Wajo

Tabel 5. Deskripsi Tingkat Motivasi Belajar Kelas Eksperimen 1

\begin{tabular}{lccccccc}
\hline \multicolumn{7}{c}{ Descriptive Statistics } \\
\hline & N & $\begin{array}{c}\text { Rang } \\
\mathbf{e}\end{array}$ & Min & Max & $\begin{array}{c}\text { Mea } \\
\mathbf{n}\end{array}$ & $\begin{array}{c}\text { Std. } \\
\text { Deviatio } \\
\text { n }\end{array}$ & Variance \\
\hline $\begin{array}{lcccccc}\text { Motivasi } \\
\text { Kelas }\end{array}$ & 22 & 23,00 & 55,00 & 78,00 & 65,73 & 6,54 & 42,78 \\
$\begin{array}{l}\text { Eksperimen 1 } \\
\begin{array}{l}\text { Valid N } \\
\text { (listwise) }\end{array}\end{array}$ & 22 & & & & & & \\
\hline
\end{tabular}

Berdasarkan tabel 5, skor maksimum pada tingkat motivasi kelas eksperimen 1 dengan menggunakan metode deduktif adalah 78, sedangkan skor minimum pada tingkat motivasi adalah 55, sehingga rata-rata yang diperoleh adalah 65,73. 
Deskripsi Motivasi Belajar yang Menggunakan Metode Induktif pada Siswa Kelas XII IPS MAN Wajo Kabupaten Wajo

Berikut ini adalah tabel hasil analisis deskriptif data motivasi belajar yang menggunakan metode induktif pada siswa kelas XII IPS MAN Wajo Kabupaten Wajo.

Tabel 6. Deskripsi Tingkat Motivasi Belajar Kelas Eksperimen 2

\begin{tabular}{lccccccc}
\hline \multicolumn{7}{c}{ Descriptive Statistics } \\
& N & Range & Min & Max & Mean & $\begin{array}{c}\text { Std. } \\
\text { Dev. }\end{array}$ & Var \\
\hline Motivasi & 2 & 22,00 & 56,00 & 78,00 & 68,23 & 7,41 & 54, \\
Kelas & 2 & & & & & & 85 \\
Eksperimen 2 & & & & & & & \\
Valid N & 2 & & & & & & \\
(listwise) & 2 & & & & & & \\
\hline
\end{tabular}

Berdasarkan tabel 6, skor maksimum pada tingkat motivasi kelas eksperimen 2 dengan menggunakan metode induktif adalah 78, sedangkan skor minimum yang diperoleh pada tingkat motivasi adalah 56 , sehingga ratarata yang diperoleh adalah 68,23 .

Perbedaan Hasil Belajar Matematika Menggunakan Metode Induktif dengan Metode Deduktif Ditinjau dari Motivasi Belajar terhadap siswa kelas XII IPS MAN Wajo Kabupaten Wajo

Data angket motivasi siswa diperoleh dari angket tentang motivasi belajar siswa. Berdasarkan data skor motivasi belajar yang diperoleh, selanjutnya dikelompokkan ke dalam tiga kategori berdasarkan rata-rata dan standar deviasi. Berikut ini hasil dari pengelompokan siswa berdasarkan kategori motivasi belajar.

Tabel 7. Hasil Pengelompokan Siswa Berdasarkan Motivasi Belajar

\begin{tabular}{cccc}
\hline $\begin{array}{c}\text { Kategori } \\
\text { Motivasi Siswa }\end{array}$ & $\begin{array}{c}\text { Eksp 1 } \\
\text { (Deduktif) }\end{array}$ & $\begin{array}{c}\text { Eksp 2 } \\
\text { (Induktif) }\end{array}$ & Jumlah \\
\hline Tinggi & 2 & 6 & 8 \\
Sedang & 16 & 11 & 27 \\
Rendah & 4 & 5 & 9 \\
Jumlah & 22 & 22 & 44 \\
\hline
\end{tabular}


a. Uji Normalitas Data

Pengujian normalitas dilakukan pada data hasil post-test dan tingkat motivasi belajar matematika kedua sampel, yaitu kelas eksperimen 1 dan kelas eksperimen 2.

Tabel 8. Uji Normalitas Hasil Belajar dan Motivasi Belajar

\begin{tabular}{|c|c|c|c|c|c|c|}
\hline \multicolumn{7}{|c|}{ Tests of Normality } \\
\hline & \multicolumn{3}{|c|}{ Kolmogorov-Smirnova } & \multicolumn{3}{|c|}{ Shapiro-Wilk } \\
\hline & $\begin{array}{l}\text { Statisti } \\
\text { c }\end{array}$ & Df & Sig. & Statistic & Df & Sig. \\
\hline HBS Eks 1 & 083 & 22 & $200^{*}$ & ,970 & 22 & ,706 \\
\hline Motivasi Eks 1 & 152 & 22 & $200^{*}$ & ,958 & 22 & 458 \\
\hline HBS Eks 2 & 135 & 22 & $200^{*}$ & 913 & 22 & ,055 \\
\hline Motivasi Eks 2 & ,161 & 22 & 141 & 893 & 22 & ,022 \\
\hline \multicolumn{7}{|c|}{$\begin{array}{l}\text { *. This is a lower bound of the true significance. } \\
\text { a. Lilliefors Significance Correction }\end{array}$} \\
\hline
\end{tabular}

$\mathrm{H}_{0}=$ berdistribusi normal jika probabilitas $>0,05$

Berdasarkan tabel 8, diperoleh:

1. Nilai statistik untuk Kolmogorov-Smirnov sebesar 0,083 dan Sig =0,200 > $0,05, \mathrm{H}_{0}$ diterima atau tidak signifikan. Dengan demikian, data post-test kelas Eksperimen 1 berdistribusi normal.

2. Nilai statistik untuk Kolmogorov-Smirnov sebesar 0,152 dan Sig =0,200 > $0,05, \mathrm{H}_{0}$ diterima atau tidak signifikan. Dengan demikian, data tingkat motivasi belajar kelas Eksperimen 1 berdistribusi normal.

3. Nilai statistik untuk Kolmogorov-Smirnov sebesar 0,135 dan Sig =0,200 > $0,05, \mathrm{H}_{0}$ diterima atau tidak signifikan. Dengan demikian, data post-test kelas eksperimen 2 berdistribusi normal.

4. Nilai statistik untuk Kolmogorov-Smirnov sebesar 0,161 dan Sig = 0,141 > $0,05, \mathrm{H}_{0}$ Diterima atau tidak signifikan. Dengan demikian, data tingkat motivasi belajar kelas Eksperimen 2 berdistribusi normal.

b. Uji Homogenitas Varians

Pengujian homogenitas dilakukan pada data hasil post-test dan tingkat motivasi belajar matematika kedua sampel, yaitu kelas eksperimen 1 dan kelas eksperimen 2. 
Tabel 9. Uji Homogenitastas Varian Hasil Belajar dan Motivasi Belajar Siswa Kelas Eksperimen 1 dan Kelas Eksperimen 2

\begin{tabular}{ccccc}
\hline \multicolumn{4}{c}{ Test of Homogeneity of Variances } & \\
\hline & $\begin{array}{c}\text { Levene } \\
\text { Statistic }\end{array}$ & df1 & df2 & Sig. \\
\hline Hasil Belajar &, 183 & 1 & 42 &, 671 \\
Motivasi Belajar &, 037 & 1 & 42 &, 848 \\
\hline
\end{tabular}

Sebagai kriteria pengujian, jika nilai Sig. lebih dari dari a $(0,05)$ maka dapat dikatakan bahwa varian dari dua atau lebih kelompok data adalah sama. Berdasarkan hasil analisis pada tabel 9, diperoleh $\mathrm{F}=0,183$; df1 = 1; df2 = 42; dan p-value = 0,671 > 0,05 atau $\mathrm{H}_{0}$ diterima. Dengan demikian, data hasil belajar homogen. Adapun untuk motivasi belajar, diperoleh $\mathrm{F}=0,037$; df1=1; df2= 42; dan Sig. = 0,848 Dengan demikian, data tingkat motivasi belajar homogen.

c. Uji Hipotesis

Analisis Variansi (ANAVA) yang digunakan untuk menguji hipotesis adalah Analisis Variansi Dua Variabel dengan Interaksi, karena berdasarkan data yang diperoleh (tabel 7), merupakan data tiga rata-rata dengan dua perlakuan (induktif dan deduktif) yang berpengaruh dan pengaruh interaksi antara kedua faktor dengan tingkatan motivasi diperhitungkan.

1. Formulasi hipotesis

1) $\mathrm{H}_{0}: \mu_{1}=\mu_{2}=\mu_{3}=0$

$\mathrm{H}_{1}$ : sekurang-kurangnya satu $\mu_{\mathrm{i}} \neq 0$

2) $\mathrm{H}_{0}: \rho_{1}=\rho_{2}=\rho_{3}=0$

$\mathrm{H}_{1}$ : sekurang-kurangnya satu $\rho_{\mathrm{j}} \neq 0$

3) $\mathrm{H}_{0}:(\mu \rho)_{11}=(\mu \rho)_{12}=\ldots(\mu \rho)_{32}=0$

$\mathrm{H}_{1}$ : sekurang-kurangnya satu $(\mu \rho)_{\mathrm{ij}} \neq 0$

2. Taraf nyata $(\alpha=5 \%=0,05)$ dan F tabel:

1) Untuk baris : $F_{0,05(1 ; 38)}=4,10$

2) Untuk kolom : $F_{0,05(2 ; 38)}=3,24$

3) Untuk interaksi : $F_{0,05(2 ; 38)}=3,24$

3. Kriteria pengujian

1) $\mathrm{H}_{0}$ diterima apabila $\mathrm{F}_{0} \leq 4,10$

$\mathrm{H}_{0}$ ditolak apabila $\mathrm{F}_{0}>4,10$

2) $\mathrm{H}_{0}$ diterima apabila $\mathrm{F}_{0} \leq 3,24$

$\mathrm{H}_{0}$ ditolak apabila $\mathrm{F}_{0}>3,24$ 
3) $\mathrm{H}_{0}$ diterima apabila $\mathrm{F}_{0} \leq 3,24$

$\mathrm{H}_{0}$ ditolak apabila $\mathrm{F}_{0}>3,24$

4. Analisis Varians

Tabel 10. Uji F (Anava) Hasil Post-test dan Tingkat Motivasi Belajar Siswa

\begin{tabular}{cccc}
\hline \multicolumn{3}{c}{ Between-Subjects Factors } \\
\hline & & Value Label & N \\
\hline \multirow{2}{*}{ Kelas Eks } & 1 & Deduktif & 22 \\
& 2 & Induktif & 22 \\
\multirow{2}{*}{ Tingkat Motivasi } & 1 & Tinggi & 8 \\
& 2 & Sedang & 27 \\
& 3 & Rendah & 9 \\
\hline
\end{tabular}

Tabel 11. Tests of Between-Subjects Effects

\begin{tabular}{|c|c|c|c|c|c|}
\hline \multicolumn{6}{|c|}{ Tests of Between-Subjects Effects } \\
\hline Dependent Variab & Hasil Belajar & & & & \\
\hline Source & $\begin{array}{l}\text { Type III Sum } \\
\text { of Squares }\end{array}$ & $\overline{\mathrm{Df}}$ & $\begin{array}{l}\text { Mean } \\
\text { Square }\end{array}$ & $\bar{F}$ & Sig. \\
\hline Corrected Model & $3309,479^{a}$ & 5 & 661,896 & $\begin{array}{r}12,06 \\
1\end{array}$ & ,000 \\
\hline Intercept & 190371,634 & 1 & $\begin{array}{r}190371,63 \\
4 \\
\end{array}$ & $\begin{array}{r}3469, \\
077 \\
\end{array}$ & ,000 \\
\hline Kelas Eks & 1916,982 & $\overline{1}$ & 1916,982 & $\begin{array}{r}34,93 \\
3\end{array}$ & , 000 \\
\hline Tingkat Motivasi & 470,382 & 2 & 235,191 & 4,286 & 021 \\
\hline $\begin{array}{l}\text { Kelas Eks* } \\
\text { Tingkat Motivasi }\end{array}$ & 429,264 & 2 & 214,632 & 3,911 & ,029 \\
\hline Error & 2085,316 & 38 & 54,877 & & \\
\hline Total & 300759,000 & 44 & & & \\
\hline Corrected Total & 5394,795 & 43 & & & \\
\hline
\end{tabular}

5. Kesimpulan:

1) Karena $F_{0}=34,933>F_{0,05(1 ; 38)}=4,10$, maka $H_{o}$ ditolak dan nilai Sig $<\alpha=0,000<0,05$, sehingga dapat disimpulkan bahwa terdapat perbedaan yang signifikan antara metode induktif dengan metode 
deduktif terhadap hasil belajar matematika siswa kelas XII IPS MAN Wajo Kabupaten Wajo.

2) Karena $\mathrm{F}_{0}=3,911>\mathrm{F}_{0,05(2 ; 38)}=3,24$, maka $\mathrm{H}_{\mathrm{o}}$ ditolak dan Sig $<\alpha=0,029<0,05$, sehingga dapat disimpulkan bahwa Terdapat perbedaan antara siswa yang memiliki motivasi tinggi, motivasi sedang dan motivasi rendah terhadap hasil belajar matematika kelas XII IPS MAN Wajo Kabupaten Wajo

3) Karena $F_{0}=4,286>F_{0,05(2 ; 38)}=3,24$, maka $H_{0}$ ditolak dan nilai Sig $<\alpha=0,021<0,05$, sehingga dapat disimpulkan bahwa terdapat perbedaan yang signifikan antara metode induktif dengan metode deduktif terhadap hasil belajar matematika ditinjau dari motivasi belajar siswa kelas XII IPS MAN Wajo Kabupaten Wajo.

\section{PEMBAHASAN}

Pembelajaran menggunakan dua metode deduktif dan induktif, di mana kelas eksperimen 1 diajar menggunakan metode deduktif, dan kelas eksperimen 2, diajar menggunakan metode induktif. Pada pelaksanaannya, siswa dibagi menjadi kelompok-kelompok kecil. Masing-masing anggota kelompok kemudian diberi tugas untuk memahami sebuah pokok bahasan dan bertanggung jawab untuk memahaminya kemudian menjelaskan kepada teman kelompoknya mengenai pokok bahasan yang dipelajari, dan mempresentasekan hasil kelompoknya di depan kelas. Secara umum, hasil pengamatan menunjukkan bahwa pembelajaran menggunakan metode induktif pada pokok bahasan Barisan dan Deret, pada umumnya menunjukkan sikap ketertarikan dan terlihat sangat antusias mengikuti proses pembelajaran.

\section{Perbedaan Hasil Belajar Matematika Menggunakan Metode Induktif dengan Metode Deduktif}

Berdasarkan hasil perhitungan analisis variansi dua variabel dengan SPSS 20, diperoleh nilai F hitung sebesar 34,933 sedangkan nilai $F$ tabel dengan derajat kebebasan (dk) pembilang 1 dan derajat kebebasan (dk) penyebut 38 pada taraf signifikan 0,05 adalah 4,10, sehingga $F$ hitung lebih besar dibandingkan dengan $\mathrm{F}$ tabel dan nilai signifikan lebih kecil dari taraf signifikan, dengan demikian hipotesis nol $\left(\mathrm{H}_{\mathrm{o}}\right)$ ditolak, yaitu hipotesis yang menyatakan terdapat perbedaan yang signifikan antara metode induktif dengan metode deduktif terhadap hasil belajar matematika siswa kelas XII IPS 
MAN Wajo Kabupaten Wajo. Hal ini sejalan dengan penelitian yang dilakukan oleh Samosir (2000) terdapat perbedaan yang signifikan antara hasil belajar para siswa yang diajar dengan cara induktif dan yang diajar dengan cara deduktif, dimana terlihat hasil belajar siswa yang mendapat pengajaran dengan cara induktif lebih baik dibandingkan dengan hasil belajar siswa yang mendapat pengajaran dengan cara deduktif. Dapat disimpulkan bahwa pembelajaran menggunakan Metode induktif terbukti lebih baik dan hasil belajar matematika siswa lebih tinggi dibandingkan pembelajaran menggunakan metode deduktif.

\section{Perbedaan Hasil Belajar Matematika Siswa yang memiliki Motivasi Tinggi, Motivasi Sedang dan Motivasi Rendah}

Berdasarkan hasil perhitungan anava dua jalur dengan SPSS 20, diperoleh nilai $\mathrm{F}$ hitung sebesar 4,286 sedangkan nilai $\mathrm{F}$ tabel dengan derajat kebebasan (dk) pembilang 2 dan derajat kebebasan (dk) penyebut 38 pada taraf signifikan 0,05 adalah 3,24, sehingga F hitung lebih besar dibandingkan dengan $\mathrm{F}$ tabel dan nilai signifikan lebih kecil dari taraf signifikan, dengan demikian hipotesis nol $\left(\mathrm{H}_{\mathrm{o}}\right)$ ditolak, yaitu hipotesis yang menyatakan Terdapat perbedaan antara siswa yang memiliki motivasi tinggi, motivasi sedang dan motivasi rendah terhadap hasil belajar matematika kelas XII IPS MAN Wajo Kabupaten Wajo. Hal ini sejalan dengan penelitian yang dilakukan oleh Al Maryanto (2013) yang menyatakan bahwa adanya korelasi antara motivasi dan prestasi belajar peserta didik. Dapat disimpulkan bahwa terdapat perbedaan antara siswa yang memiliki motivasi tinggi, motivasi sedang dan motivasi rendah terhadap hasil belajar matematika.

\section{Perbedaan Hasil Belajar Matematika Menggunakan Metode Induktif dengan Metode Deduktif Ditinjau dari Motivasi Belajar}

Berdasarkan hasil perhitungan anava dua jalur dengan SPSS 20, diperoleh nilai $\mathrm{F}$ hitung sebesar 3,911 sedangkan nilai F tabel dengan derajat kebebasan (dk) pembilang 2 dan derajat kebebasan (dk) penyebut 38 pada taraf signifikan 0,05 adalah 3,24, sehingga $F$ hitung lebih besar dibandingkan dengan $\mathrm{F}$ tabel dan nilai signifikan lebih kecil dari taraf signifikan, dengan demikian hipotesis nol $\left(\mathrm{H}_{\mathrm{o}}\right)$ ditolak, yaitu hipotesis yang menyatakan Terdapat perbedaan yang signifikan antara metode induktif dengan metode deduktif terhadap hasil belajar matematika ditinjau dari motivasi belajar siswa kelas XII IPS MAN Wajo Kabupaten Wajo. Dugaan awal perbelajaran 
menggunakan metode induktif lebih baik ditinjau dari motivasi belajar matematika dan hasil belajar matematka siswa. Langkah-langkah pembelajaran menggunakan metode induktif menunjukkan adanya rangsangan yang lebih dalam meningkatkan motivasi belajar matematika dan hasil belajar siswa. Secara umum, langkah-langkah pelaksanaan pembelajaran menggunakan metode induktif dan metode deduktif memiliki kesamaan dalam hal diskusi.

Pembelajaran menggunakan metode induktif membuat siswa lebih termotivasi belajar matematika dibandingkan dengan pembelajaran menggunakan metode deduktif, ini dapat dilihat pada hasil data angket motivasi belajar matematika siswa dan dengan pengkategoriannya. Winarso (2014) yang menyatakan bahwa, siswa lebih terlibat dalam mendapatkan konsep atau prinsip dan lebih termotivasi mengikuti proses pembelajaran dengan menggunakan metode induktif, dibandingkan menggunakan metode deduktif. Dapat disimpulkan bahwa siswa-siswa yang mendapat pembelajaran menggunakan metode induktif, terbukti lebih aktif dan lebih termotivasi mengikuti pembelajaran sehingga, hasil belajar matematika yang diperoleh siswa lebih tinggi dibandingkan pembelajaran menggunakan metode deduktif.

\section{SIMPULAN}

Berdasarkan hasil penelitian dan pembahasan sebelumnya, maka diperoleh beberapa kesimpulan sebagai berikut:

a. Hasil post-test di kelas eksperimen 1, yang diajar dengan menggunakan pembelajaran pendekatan deduktif pada siswa kelas XII IPS 1 pokok bahasan Barisan dan Deret diperoleh skor maksimum 90,00 sedangkan skor minimum 56,00 dan rata-rata yang diperoleh adalah 74,91. Hasil posttest yang diberikan pada siswa di kelas eksperimen 2, yang diajar dengan menggunakan pembelajaran pendekatan induktif pada siswa kelas XII IPS 3 pokok bahasan Barisan dan Deret diperoleh skor maksimum adalah 100, sedangkan skor minimum 77,00 dan rata-rata yang diperoleh adalah 88,95. Berdasarkan angket motivasi belajar matematika siswa di kelas eksperimen 1, yang diajar dengan menggunakan pembelajaran pendekatan deduktif pada siswa kelas XII IPS ${ }_{1}$ pokok bahasan Barisan dan Deret diketahui bahwa skor maksimum yang diperoleh adalah 78,00 sedangkan skor minimum yang diperoleh pada tingkat motivasi adalah 55,00 dan rata-rata yang diperoleh adalah 65,73 . Sedangkan angket 
motivasi belajar matematika siswa di kelas eksperimen 2, yang diajar dengan menggunakan pembelajaran pendekatan induktif pada siswa kelas XII IPS 3 pokok bahasan Barisan dan Deret diketahui bahwa skor maksimum yang diperoleh adalah 78,00 sedangkan skor minimum adalah 56,00 dan rata-rata yang diperoleh adalah 68,23.

b. Berdasarkan hasil perhitungan analisis variansi dua variabel, pada tabel uji F dengan bantuan perangkat lunak SPSS 20:

1. Karena $\mathrm{F}_{0}=34,933>\mathrm{F}_{0,05(1 ; 38)}=4,10$, maka $\mathrm{H}_{\mathrm{o}}$ ditolak dan nilai Sig. $<\alpha$ $=0,000<0,05$, sehingga dapat disimpulkan bahwa Terdapat perbedaan yang signifikan antara Metode Induktif dengan Metode Deduktif terhadap Hasil Belajar Matematika Siswa kelas XII IPS MAN Wajo Kabupaten Wajo.

2. Karena $\mathrm{F}_{0}=3,911>\mathrm{F}_{0,05(2 ; 38)}=3,24$, maka $\mathrm{H}_{\mathrm{o}}$ ditolak dan nilai Sig. $<\alpha=$ $0,029<0,05$, sehingga dapat disimpulkan bahwa Terdapat perbedaan antara siswa yang memiliki motivasi tinggi, motivasi sedang dan motivasi rendah terhadap hasil belajar matematika kelas XII IPS MAN Wajo Kabupaten Wajo.

3. Karena $\mathrm{F}_{0}=4,286>\mathrm{F}_{0,05(2 ; 38)}=3,24$, maka $\mathrm{H}_{\mathrm{o}}$ ditolak dan nilai Sig. $<\alpha=$ $0,021<0,05$, sehingga dapat disimpulkan bahwa Terdapat perbedaan yang signifikan antara Metode Induktif dengan Metode Deduktif terhadap Hasil Belajar Matematika ditinjau dari Motivasi belajar Siswa kelas XII IPS MAN Wajo Kabupaten Wajo.

\section{DAFTAR PUSTAKA}

Angriani, A. D. (2014). Meningkatkan hasil belajar matematika melalui pemberian kuis dengan umpan balik pada siswa kelas X6 SMA Negeri 2 Sinjai. MaPan : Jurnal Matematika dan Pembelajaran, 2(1), 1-16.

Aqib, Z. (2014). Model-model, media dan strategi pembelajaran kontekstual (inovatif). Bandung: Yrama Widya.

Aunurrahman (2011). Belajar dan pembelajaran. Bandung: Alfabeta.

Djumingin, S. (2011). Strategi dan aplikasi bahasa dan sastra. Makassar: UNM.

Jihad, A. \& Haris, A. (2012). Evaluasi pembelajaran. Yokyakarta: Multi Presindo.

Maryanto, A. \& Mundilarto. (2013). Keefektifan strategi induktif dan deduktif dalam pembelejaran IPA untuk meningkatkan prestasi belajar dan 
Perbandingan Metode Deduktif dengan....

motivasi belajar IPA siswa SMP. Jurnal Program Pascasarjana Universitas Negeri Yokyakarta.

Sanjaya, W. (2012). Strategi pembelajaran berorientasi standar proses pendidikan. Jakarta: Kencana Prenada Media Group. 